\title{
Crystallization and microstructural behaviour of strontium titanate borosilicate glass ceramics with $\mathrm{Bi}_{2} \mathrm{O}_{3}$ addition
}

\author{
O P THAKUR ${ }^{\dagger}$, DEVENDRA KUMAR*, OM PARKASH** and \\ LAKSHMAN PANDEY $\mathbf{Y}^{\dagger \dagger}$ \\ Department of Ceramic Engineering, **School of Materials Science and Technology, \\ Institute of Technology, Banaras Hindu University, Varanasi 221005 , India \\ ${ }^{\dagger}$ Present address: Ferrite Division, Solid State Physics Laboratory, Delhi 110054, India \\ ${ }^{+}$Department of Post-graduate Studies and Research in Physics, Rani Durgavati Vish- \\ wavidyalaya, Jabalpur 482001 , India
}

MS received 23 May 1996; revised 8 October 1996

\begin{abstract}
Glasses in the system $(65-x)\left[\mathrm{SrO} \cdot \mathrm{TiO}_{2}\right]-(35)\left[2 \mathrm{SiO}_{2} \cdot \mathrm{B}_{2} \mathrm{O}_{3}\right]-(x)\left[\mathrm{Bi}_{2} \mathrm{O}_{3}\right]$ where $x=1,5,10$ (wt \%) prepared by melting in alumina crucible $(1375-1575 \mathrm{~K}$ ), were subjected to different heat treatment schedules followed by DTA studies. Crystallization study showed the formation of $\mathrm{Sr}_{2} \mathrm{~B}_{2} \mathrm{O}_{5}$ as major phase at low temperature $\left(\approx 950^{\circ} \mathrm{C}\right)$ heat treatment. At high temperatures, $\mathrm{TiO}_{2}$ and $\mathrm{SrTiO}_{3}$ with or without $\mathrm{Sr}_{2} \mathrm{~B}_{2} \mathrm{O}_{5}$ crystallize out depending on heat treatment. In this paper, the influence of variation in composition, thermal treatment on the nature of crystallizing phases as well as on the resulting microstructures are investigated through XRD, IR and SEM. Uniform crystallization was achieved by suitable addition of $\mathrm{Bi}_{2} \mathrm{O}_{3}$ and proper heat treatment.
\end{abstract}

Keywords. Glass ceramics; crystallization; microstructure; dielectric behaviour.

\section{Introduction}

Glass ceramic process is an efficient way of producing an uniform, pore-free and fine grained microstructure which is highly desirable in ferroelectric materials (McMillan 1979; Parkash et al 1986). Extensive studies have been reported on the crystallization and dielectric behaviour of ferroelectric glass ceramics, specifically $\mathrm{BaTiO}_{3}$ (Herczog 1964; Kokubo et al 1968), $\mathrm{PbTiO}_{3}$ and $\mathrm{NaNbO}_{3}$ (Martin 1965; Grossman and Isard 1969; Kokubo and Tashiro 1973/74). These studies had shown that both the parent glass composition and heat treatment schedule determine the crystalline phase constitution, microstructure and hence the dielectric properties of respective glass ceramic materials.

Glass ceramics based on $\mathrm{SrTiO}_{3}$ have found applications in cryogenic capacitive temperature sensors (Lawless 1972). These glass ceramics may also be suitable for the applications where thermal stability of dielectric behaviour is desired (Swartz et al 1983). Studies on strontium titanate aluminosilicate glass ceramics had been reported by many authors for their crystallization, dielectric and microstructural behaviour (Swartz et al 1988a, b). They found that the purity of raw materials influences the crystallization phenomena drastically. Compositions with reagent grade chemicals reveal the formation of $\mathrm{SrTiO}_{3}$ phase at low crystallization temperature whereas fresnoite $\left(\mathrm{Sr}_{2} \mathrm{TiSi}_{2} \mathrm{O}_{8}\right)$ was the primary crystalline phase using high purity chemicals. Moreover, the crystallization behaviour was

*Author for correspondence 
further complicated by the presence of several other unidentified phases. Nucleation treatment also affects the crystallization and dielectric behaviour of resulting glass ceramics.

Recently, investigations into the crystallization, microstructural and dielectric behaviour of strontium titanate borosilicate glass ceramics showed that the resulting glass ceramics mainly consisted of $\mathrm{Sr}_{2} \mathrm{~B}_{2} \mathrm{O}_{5}, \mathrm{TiO}_{2}, \mathrm{Sr}_{3} \mathrm{Ti}_{2} \mathrm{O}_{7}$ and some other unidentified phases (Thakur et al 1995a). Suitable addition of alkali oxide and proper heat treatment schedule resulted in the precipitation of $\mathrm{SrTiO}_{3}$ as a major phase (Thakur et al 1995b).

The addition of alkali oxide $\left(\mathrm{K}_{2} \mathrm{O}\right)$ and transition metal oxide $\mathrm{CoO}$ has been found to influence the crystallization behaviour of strontium titanate borosilicate glass ceramics (Thakur et al 1995b, 1996). The effect of addition of $\mathrm{Bi}_{2} \mathrm{O}_{3}$ on the crystallization and resulting microstructure of $\left(\mathrm{SrO} \cdot \mathrm{TiO}_{2}\right)-\left(2 \mathrm{SiO}_{2} \cdot \mathrm{B}_{2} \mathrm{O}_{3}\right)$ glass has been investigated and the results of these investigations are reported in this paper.

\section{Experimental}

Batches of $25 \mathrm{~g}$ of the appropriate mixture of $\mathrm{SrCO}_{3}, \mathrm{TiO}_{2}, \mathrm{SiO}_{2}, \mathrm{H}_{3} \mathrm{BO}_{3}$ and $\mathrm{Bi}_{2} \mathrm{O}_{3}$ were taken in a high grade alumina crucible. Chemicals used were of purity better than $99 \%$. The composition of different glasses are given in table 1. Batches were melted in a globar furnace at $1375-1575 \mathrm{~K}$ for $1 \mathrm{~h}$. The melt was intermittently stirred, poured into an aluminium mould and pressed quickly by another plate to form a slab of uniform thickness. Glass specimens were annealed for $3 \mathrm{~h}$ at $875 \mathrm{~K}$ and furnace cooled to room temperature. Annealed samples were examined for their amorphosity by X-ray diffraction.

Infrared spectra for powdered specimens in the form of $\mathrm{KBr}$ pellet were recorded in $400-3000 \mathrm{~cm}^{-1}$ range with a Beckman IR 4200 spectrophotometer. Differential thermal analysis was conducted on Perkin-Elmer DTA 1700 at a heating rate of $15 \mathrm{~K} / \mathrm{min}$. The glasses were subjected to different heat treatment schedules in the temperature range $1075-1275 \mathrm{~K}$ to form glass ceramic samples. The crystalline phases in the glass ceramic samples were identified by X-ray diffraction using a Rich-Seifert ID 3000 diffractometer using $\mathrm{Cu}-\mathrm{K} \alpha$ radiation. The information regarding size and morphology of crystals in the glassy matrix was obtained by scanning electron microscopy (Philips, Model PSEM 500). Samples for SEM were prepared by polishing using fine $\mathrm{Al}_{2} \mathrm{O}_{3}$ powder, and etching for $30 \mathrm{sec}$ with an aqueous solution of $1 \% \mathrm{HCl}$ and $0.1 \% \mathrm{HF}$. A layer of $\mathrm{Au}-\mathrm{Pd}$ was then evaporated onto the sample surface to prevent charge build up.

Table 1. Glass compositions (wt \%)

\begin{tabular}{lccccccc}
\hline & & & \multicolumn{4}{c}{ DTA peaks $\left({ }^{\circ} \mathrm{C}\right)$} \\
\cline { 5 - 8 } Glass No. & $\left(\mathrm{SrO}^{n} \cdot \mathrm{TiO}_{2}\right)$ & $\left(2 \mathrm{SiO}_{2} \cdot \mathrm{B}_{2} \mathrm{O}_{3}\right)$ & $\mathrm{Bi}_{2} \mathrm{O}_{3}$ & $T_{\mathrm{B}}$ & $T_{\mathrm{cl}}$ & $T_{\mathrm{c} 2}$ & $T_{\mathrm{c} 3}$ \\
\hline B1 & 64 & 35 & 1 & 690 & 840 & 860 & 980 \\
B5 & 60 & 35 & 5 & 670 & 765 & 820 & 990 \\
B10 & 55 & 35 & 10 & 675 & 730 & 835 & 1000 \\
\hline
\end{tabular}




\section{Results and discussion}

\subsection{DTA study}

Figure 1 shows the DTA patterns for glasses B1, B5 and B10. Glass transition temperatures obtained for these glasses were around $675^{\circ} \mathrm{C}$. Crystallization temperatures range from 750 to $1000^{\circ} \mathrm{C}$ for these glasses. It is evident from figure 1 that there are three exothermic peaks representing crystallization of different phases. It is observed that the difference between exothermic peaks increases with the concentration of $\mathrm{Bi}_{2} \mathrm{O}_{3}$ in base glass. The DTA peaks for different glasses are listed in table 1.
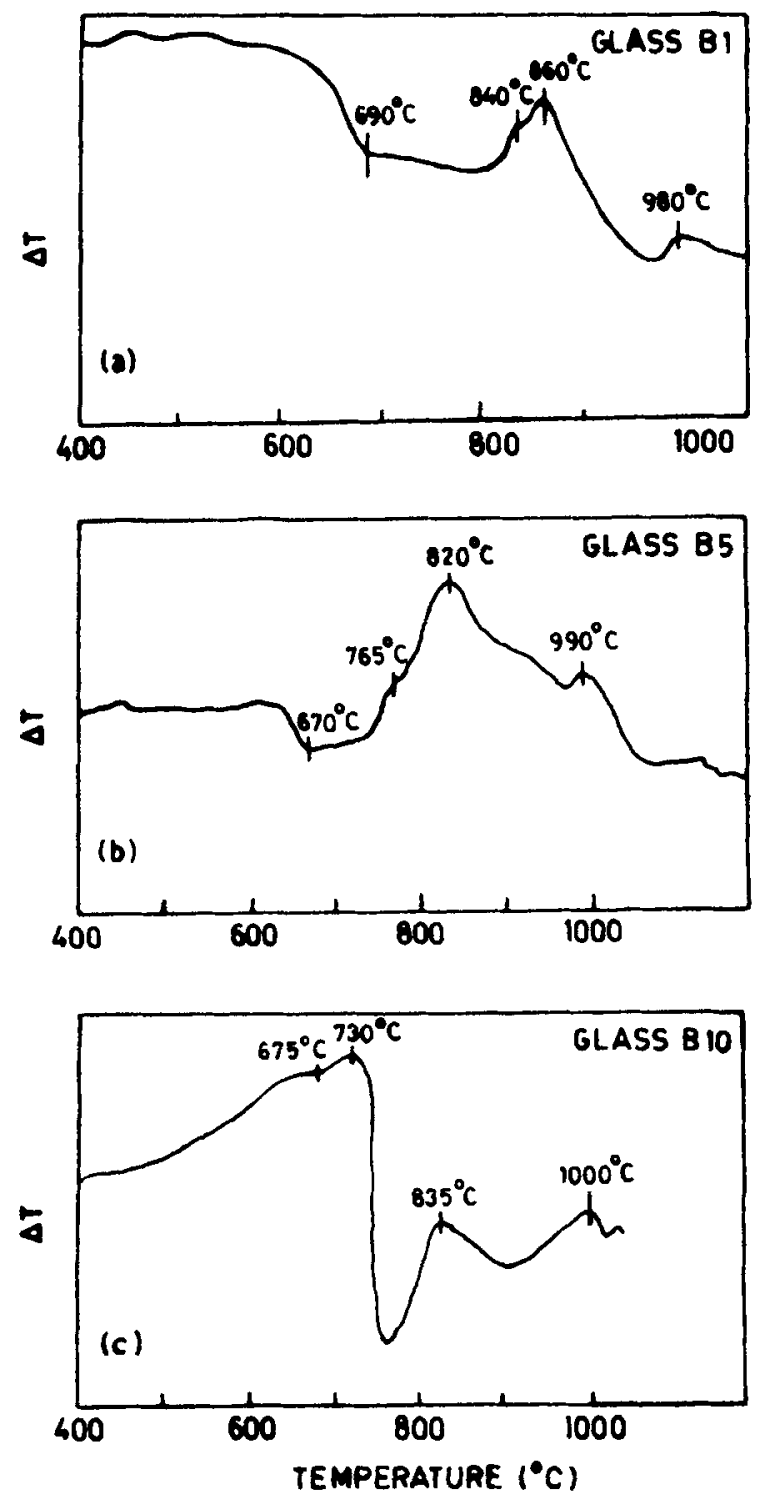

Figure 1. DTA pattern for glasses (a) B1, (b) B5 and (c) B10. 
The high temperature crystallization peak near $1000^{\circ} \mathrm{C}$ shifts slightly to higher temperature while the lower two crystallization peaks $T_{\mathrm{c} 1}$ and $T_{\mathrm{c} 2}$ shift to lower temperature with increasing concentration of $\mathrm{Bi}_{2} \mathrm{O}_{3}$. The shift in the first crystallization peak $T_{\mathrm{cl}}$ is large resulting in increased separation with second crystallization peak $T_{\mathrm{c} 2}$. A large drop in DTA curve for glass $\mathrm{B} 10$ after $730^{\circ} \mathrm{C}$ (figure $1 \mathrm{c}$ ) may be attributed to partial softening of glass which in turn helps in the crystallization of $\mathrm{SrTiO}_{3}$ phase in glass ceramics at higher temperatures as discussed in later section.
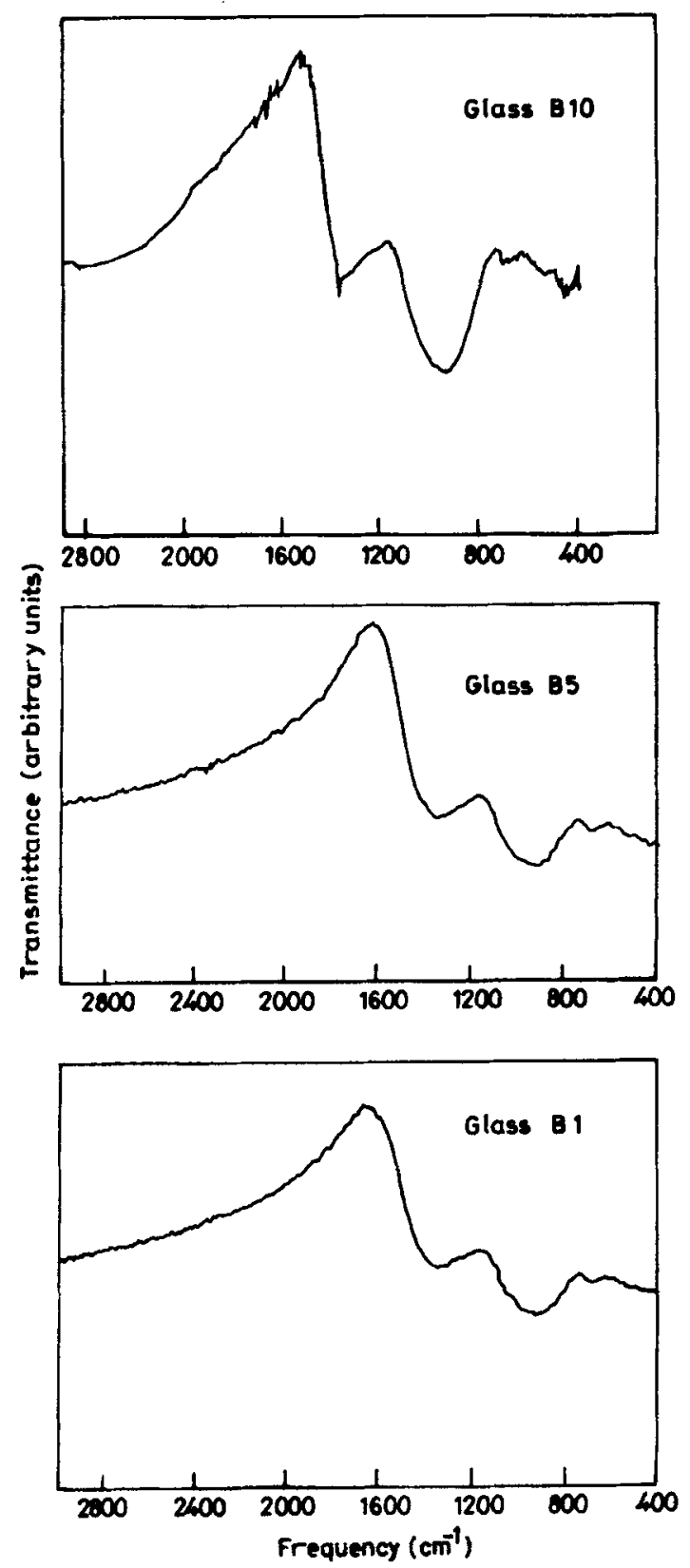

Figure 2. Infrared spectra of glasses B1, B5 and B10. 


\subsection{IR study}

In binary bismuth borate glasses containing up to $45 \mathrm{~mol} \% \mathrm{Bi}_{2} \mathrm{O}_{3}$ (Bishay and Maghrabi 1969), bismuth oxide appears to affect the structure in three different ways: (i) it gives part of its oxygen to the boron to create four-coordinated sites, (ii) it precipitates in the structure by forming $\mathrm{BiO}_{3}$ group of the $\mathrm{C}_{3 \mathrm{v}}$ type and (iii) it introduces some non-bridging oxygens in the structure.

In the present glasses (figure 2), the strong absorption band at about $1380 \mathrm{~cm}^{-1}$ is attributed to the B-O-B linkage (Anderson et al 1955; Krogh-Moe 1965) whereas the weaker bands at $\approx 720 \mathrm{~cm}^{-1}$ and $\approx 500 \mathrm{~cm}^{-1}$ arise due to bending and rocking motion of the B-O-B linkages within the glassy network. The presence of an intense band at $\approx 950 \mathrm{~cm}^{-1}$ in the IR spectrum may be assigned to the nonbridging oxygen-Si stretch (Simon 1960) and the weaker band at $\approx 460 \mathrm{~cm}^{-1}$ is generally associated with bond bending vibration of $\mathrm{Si}-\mathrm{O}-\mathrm{Si}$. The absorption peak in the region $1360 \mathrm{~cm}^{-1}$ shifts to lower frequency for glass $\mathrm{B} 5$ whereas for glass $\mathrm{B} 10$ it is being shifted to higher frequency. This may be ascribed to the transition from $\mathrm{BO}_{3}$ molecular structure to $\mathrm{BO}_{4}$ molecules. There is no major change observed in other absorption peaks within experimental accuracy $\left( \pm 5 \mathrm{~cm}^{-1}\right)$.

From IR study it may be inferred that when the content of $\mathrm{Bi}_{2} \mathrm{O}_{3}$ in base glass is increased to $5 \mathrm{wt} \%$, it introduces some non-bridging oxygens in the structure. Further addition of bismuth oxide $(10 \mathrm{wt} \%)$ may possibly render a part of its oxygen to boron creating four coordinated sites.

\subsection{Crystallization behaviour}

Different heat treatment schedules for the preparation of various glass ceramic samples are given in table 2. Major crystallizing phases in glass ceramic samples are also listed in table 2. The XRD pattern of glass ceramic B1 heat treated at lower crystallization

Table 2. Heat treatment schedules and crystalline phase constituents.

\begin{tabular}{|c|c|c|c|c|c|}
\hline Glass No. & $\begin{array}{l}\text { Glass } \\
\text { ceramic No. }\end{array}$ & $\begin{array}{l}\text { Heating } \\
\text { rate }\left({ }^{\circ} \mathrm{C} / \mathrm{m}\right)\end{array}$ & $\begin{array}{l}\text { Heating } \\
\text { time (h) }\end{array}$ & $\begin{array}{l}\text { Temperature } \\
\left({ }^{\circ} \mathrm{C}\right)\end{array}$ & Crystallizing phases \\
\hline \multirow[t]{8}{*}{ B1 } & B1A & 2 & 6 & 800 & \multirow{8}{*}{$\begin{array}{l}\mathrm{Sr}_{2} \mathrm{~B}_{2} \mathrm{O}_{5}, \mathrm{Sr}_{3} \mathrm{Ti}_{2} \mathrm{O}_{7}, \mathrm{TiO}_{2} \text { (rutile) } \\
\mathrm{Sr}_{2} \mathrm{~B}_{2} \mathrm{O}_{5}, \mathrm{Sr}_{3} \mathrm{Ti}_{2} \mathrm{O}_{7}, \mathrm{TiO}_{2} \text { (rutile) } \\
\mathrm{Sr}_{2} \mathrm{~B}_{2} \mathrm{O}_{5}, \mathrm{Sr}_{3} \mathrm{Ti}_{2} \mathrm{O}_{7}, \mathrm{TiO}_{2} \text { (rutile) } \\
\mathrm{Sr}_{2} \mathrm{~B}_{2} \mathrm{O}_{5}, \mathrm{TiO}_{2} \text { (rutile), } \mathrm{Sr}_{3} \mathrm{Ti}_{2} \mathrm{O}_{7} \\
\mathrm{Sr}_{2} \mathrm{~B}_{2} \mathrm{O}_{5}, \mathrm{TiO}_{2} \text { (rutile), } \mathrm{Sr}_{3} \mathrm{Ti}_{2} \mathrm{O}_{7} \\
\mathrm{Sr}_{2} \mathrm{~B}_{2} \mathrm{O}_{5}, \mathrm{Sr}_{3} \mathrm{Ti}_{2} \mathrm{O}_{7}, \mathrm{TiO}_{2} \text { (rutile) } \\
\mathrm{Sr}_{2} \mathrm{~B}_{2} \mathrm{O}_{5}, \mathrm{TiO}_{2} \text { (rutile), } \mathrm{Sr}_{3} \mathrm{Ti}_{2} \mathrm{O}_{7} \\
\mathrm{TiO}_{2} \text { (rutile), } \mathrm{SrTiO}_{3}\end{array}$} \\
\hline & B1B & 5 & 0 & 900 & \\
\hline & $\mathrm{B} 1 \mathrm{C}$ & 5 & 3 & 900 & \\
\hline & B1D & Direct & 6 & 900 & \\
\hline & B1E & 2 & 6 & 900 & \\
\hline & B1F & 5 & 3 & 950 & \\
\hline & $\mathrm{B} 1 \mathrm{G}$ & 2 & 6 & 1000 & \\
\hline & $\mathrm{B} 1 \mathrm{H}$ & Direct & 6 & 1000 & \\
\hline \multirow[t]{4}{*}{ B5 } & B5A & 5 & 3 & 900 & \multirow{4}{*}{$\begin{array}{l}\mathrm{Sr}_{2} \mathrm{~B}_{2} \mathrm{O}_{5}, \mathrm{TiO}_{2} \text { (rutile), } \mathrm{Sr}_{3} \mathrm{Ti}_{2} \mathrm{O}_{7} \\
\mathrm{TiO}_{2} \text { (rutile), } \mathrm{Sr}_{2} \mathrm{~B}_{2} \mathrm{O}_{5}, \mathrm{Sr}_{3} \mathrm{Ti}_{2} \mathrm{O}_{7} \\
\mathrm{TiO}_{2} \text { (rutile), } \mathrm{Sr}_{2} \mathrm{~B}_{2} \mathrm{O}_{5} \\
\mathrm{TiO}_{2} \text { (rutile), } \mathrm{Sr}_{3} \mathrm{Ti}_{2} \mathrm{O}_{7}, \mathrm{Sr}_{2} \mathrm{~B}_{2} \mathrm{O}_{5}\end{array}$} \\
\hline & B5B & 5 & 3 & 950 & \\
\hline & B5C & 5 & 1.5 & 1000 & \\
\hline & B5D & 5 & 3 & 1000 & \\
\hline \multirow[t]{4}{*}{ B10 } & $\mathrm{B} 10 \mathrm{~A}$ & 5 & 3 & 900 & \multirow{4}{*}{$\begin{array}{l}\mathrm{Sr}_{2} \mathrm{~B}_{2} \mathrm{O}_{5}, \mathrm{Sr}_{3} \mathrm{Ti}_{2} \mathrm{O}_{7}, \mathrm{TiO}_{2} \text { (rutile) } \\
\mathrm{Sr}_{2} \mathrm{~B}_{2} \mathrm{O}_{5}, \mathrm{Sr}_{3} \mathrm{Ti}_{2} \mathrm{O}_{7} \\
\mathrm{Sr}_{2} \mathrm{~B}_{2} \mathrm{O}_{5}, \mathrm{Sr}_{3} \mathrm{Ti}_{2} \mathrm{O}_{7}, \mathrm{TiO}_{2} \text { (rutile) } \\
\mathrm{SrTiO}_{3}, \mathrm{TiO}_{2} \text { (rutile) }\end{array}$} \\
\hline & B10B & 5 & 3 & 950 & \\
\hline & $\mathrm{B} 10 \mathrm{C}$ & Direct & 3 & 950 & \\
\hline & B10D* & 5 & 3 & 1000 & \\
\hline
\end{tabular}

*This glass sample was heat treated at $950^{\circ} \mathrm{C}$ for $6 \mathrm{~h}$ prior to the tabulated schedule. 


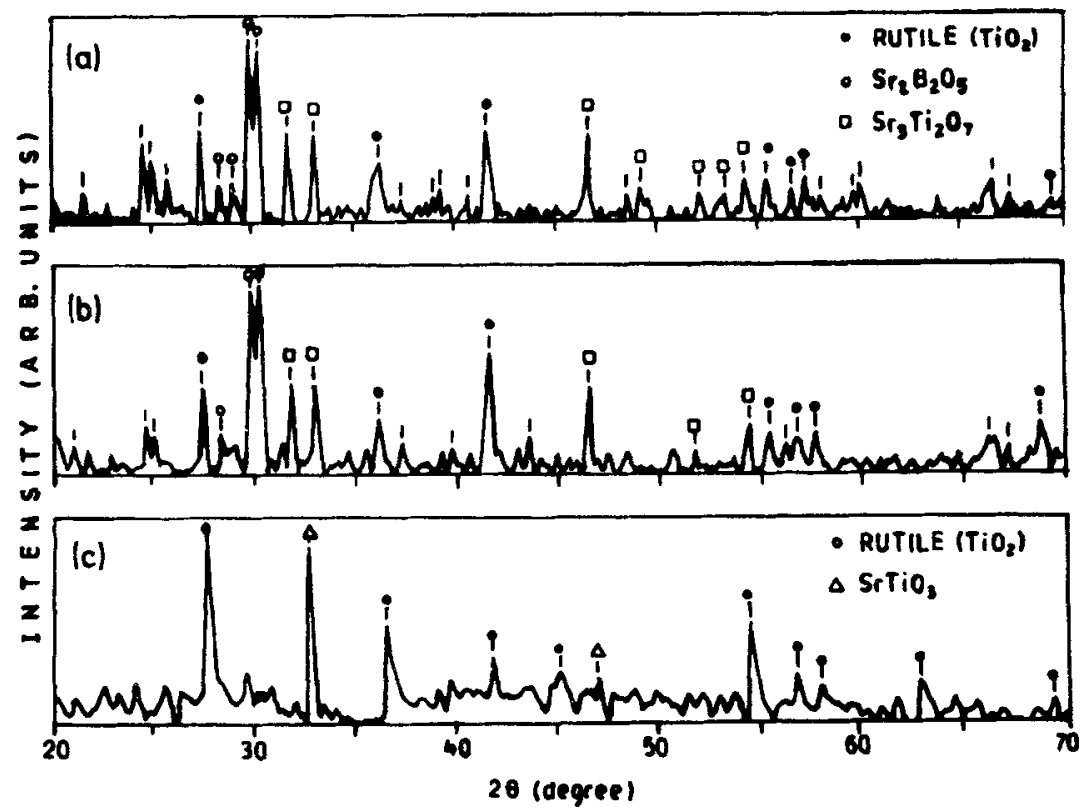

Figure 3. XRD patterns for glass ceramic sample nos. (a) B1E, (b) B1F and (c) BiH.

temperature $\left(\leqslant 900^{\circ} \mathrm{C}\right.$ ) with no holding time reveals traces of strontium borate phase and some form of strontium borosilicate phase. Longer duration of crystallization at the same temperature distinctly shows the precipitation of $\mathrm{Sr}_{2} \mathrm{~B}_{2} \mathrm{O}_{5}, \mathrm{Sr}_{3} \mathrm{Ti}_{2} \mathrm{O}_{7}$ and $\mathrm{TiO}_{2}$ (rutile) phases as shown in figure 3. It is clear that the longer duration of heat treatment at lower temperature results in the precipitation of rutile phase whereas in case of base glass, higher temperature treatment results in the crystallization of rutile phase (Thakur et al $1995 \mathrm{a})$. At higher crystallization temperature $\left(\approx 950^{\circ} \mathrm{C}\right)$, there is no major change observed in the crystalline phase constitution (figure $3 b$ ). Only the intensity of corresponding peaks has been increased, which shows major crystallization of constituting phases. In most of the cases, a major crystalline phase is strontium borate followed by $\mathrm{Sr}_{3} \mathrm{Ti}_{2} \mathrm{O}_{7}$ and rutile phases, besides traces of unidentified phases. Glass $\mathrm{B} 1$ when heated slowly $\left(2^{\circ} \mathrm{C} / \mathrm{min}\right)$ up to $1000^{\circ} \mathrm{C}$ and held for $6 \mathrm{~h}$ exhibits the precipitation of $\mathrm{Sr}_{2} \mathrm{~B}_{2} \mathrm{O}_{5}, \mathrm{TiO}_{2}$ and $\mathrm{Sr}_{3} \mathrm{Ti}_{2} \mathrm{O}_{7}$ phases. In one treatment the glass $\mathrm{B} 1$ was directly inserted into the furnace at $1000^{\circ} \mathrm{C}$ for $6 \mathrm{~h}$ (figure $3 \mathrm{c}$ ). X-ray diffraction study of the resulting glass ceramic samples reveals the formation of rutile and $\mathrm{SrTiO}_{3}$ phases. It can be said that when glass $\mathrm{B} 1$ is crystallized with slow heating rate, $\mathrm{SrO}$ present in glass is being used up in the precipitation of $\mathrm{Sr}_{2} \mathrm{~B}_{2} \mathrm{O}_{5}$ and $\mathrm{Sr}_{3} \mathrm{Ti}_{2} \mathrm{O}_{7}$ phases. At higher temperatures, proper amount of $\mathrm{SrO}$ is not available for the precipitation of $\mathrm{SrTiO}_{3}$. But when glass B1 is being crystallized by inserting the glass specimen directly into the furnace at higher temperature, $\mathrm{SrTiO}_{3}$ precipitated out because of the sufficient amount of $\mathrm{SrO}$ is available to react with $\mathrm{TiO}_{2}$ in test glass samples.

Figure 4 depicts the XRD patterns of glass $\mathrm{B} 5$ crystallized at different temperatures. When glass $\mathrm{B} 5$ is crystallized at $900^{\circ} \mathrm{C}$ for $3 \mathrm{~h}$ (figure $4 \mathrm{a}$ ), $\mathrm{Sr}_{2} \mathrm{~B}_{2} \mathrm{O}_{5}$ does precipitate in a major amount followed by rutile and $\mathrm{Sr}_{3} \mathrm{Ti}_{2} \mathrm{O}_{7}$. Heat treatment at $950^{\circ} \mathrm{C}$ (figure $4 \mathrm{~b}$ ) assists in the crystallization of rutile phase which appears as a primary constituent. Higher crystallization temperature $\left(1000^{\circ} \mathrm{C}\right.$ ) for this glass B5 (figure $4 \mathrm{c}$ ) results in the precipitation of rutile and strontium borate phases. 

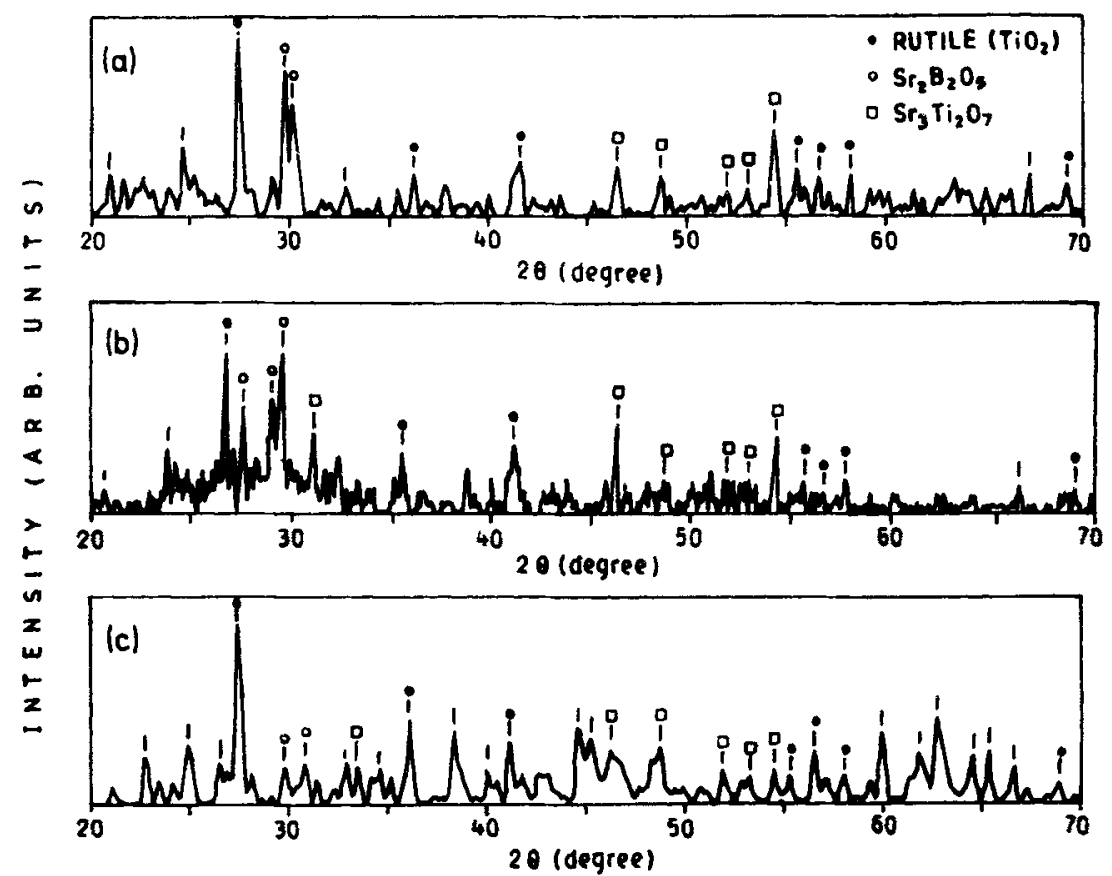

Figure 4. XRD patterns for glass ceramic sample nos. (a) B5A, (b) B5B and (c) B5D.

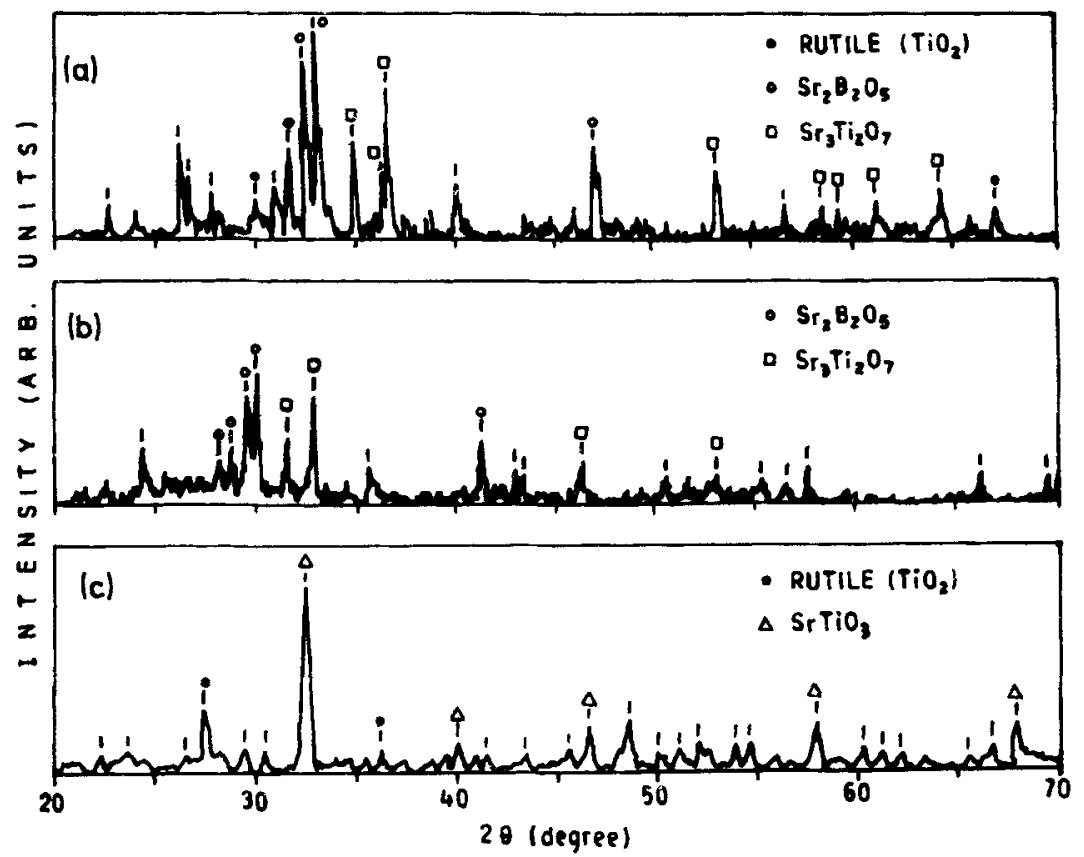

Figure 5. XRD patterns for glass ceramic sample nos. (a) B10A, (b) B10B and (c) B10D.

Heat treatment of $\mathrm{B} 10$ glass at $900^{\circ} \mathrm{C}$ for $3 \mathrm{~h}$ as shown in figure $5 \mathrm{a}$ results in the constitution of glass ceramics containing $\mathrm{Sr}_{2} \mathrm{~B}_{2} \mathrm{O}_{5}, \mathrm{Sr}_{3} \mathrm{Ti}_{2} \mathrm{O}_{7}$ and rutile phases. Further increment in crystallization temperature $\left(950^{\circ} \mathrm{C}\right)$ leads to the disappearance of 
rutile phase (figure 5b) which might be used up in the formation of more $\mathrm{Sr}_{3} \mathrm{Ti}_{2} \mathrm{O}_{7}$ phase. If the glass sample is directly inserted into the furnace at $950^{\circ} \mathrm{C}$, it seems that there was no time available for the consumption of whole rutile phase in the formation of $\mathrm{Sr}_{3} \mathrm{Ti}_{2} \mathrm{O}_{7}$. Thereby rutile phase again appears for this heat treatment schedule. When the crystallization temperature of glass ceramic (obtained by the heat treatment at $950^{\circ} \mathrm{C}$ for $6 \mathrm{~h}$ ) was raised to $1000^{\circ} \mathrm{C}$ for $3 \mathrm{~h}$ (figure $5 \mathrm{c}$ ), the resultant glass ceramic consisted of strontium titante phase followed by rutile in a meagre amount. It seems that in presence of higher concentration of $\mathrm{Bi}_{2} \mathrm{O}_{3}$ there is some structural change in the glass having 4-fold coordinated boron (Bishay and Maghrabi 1969). The presence of such structural change helps in a reaction or redissolution of earlier precipitated $\mathrm{Sr}_{2} \mathrm{~B}_{2} \mathrm{O}_{5}$ and $\mathrm{Sr}_{3} \mathrm{Ti}_{2} \mathrm{O}_{7}$ phases to give $\mathrm{SrTiO}_{3}$ phase. Similar results have been observed for the strontium titanate borosilicate glass with $\mathrm{K}_{2} \mathrm{O}$ addition (Thakur et al 1995b). The reactions may proceed as follows:

$$
\begin{aligned}
& 2 \mathrm{Sr}_{2} \mathrm{~B}_{2} \mathrm{O}_{5}+3 \mathrm{TiO}_{2} \text { (glass) } \rightarrow \mathrm{SrTiO}_{3}+\mathrm{Sr}_{3} \mathrm{Ti}_{2} \mathrm{O}_{7}+2 \mathrm{~B}_{2} \mathrm{O}_{3}, \\
& \mathrm{Sr}_{3} \mathrm{Ti}_{2} \mathrm{O}_{7}+\mathrm{TiO}_{2} \text { (glass) } \rightarrow 3 \mathrm{SrTiO}_{3} .
\end{aligned}
$$

In the absence of such structural changes no reaction takes place between earlier formed $\mathrm{Sr}_{2} \mathrm{~B}_{2} \mathrm{O}_{5}$ and $\mathrm{Sr}_{3} \mathrm{Ti}_{2} \mathrm{O}_{7}$ phases and no $\mathrm{SrTiO}_{3}$ phase precipitates out.

\subsection{Microstructural behaviour}

Scanning electron micrograph for some selected glass ceramic samples are presented in figure 6. Addition of $\mathrm{Bi}_{2} \mathrm{O}_{3}$ in base glass results in the precipitation of strontium borate as a major phase in resulting glass ceramic samples. Crystallites of acicular and needle-type represent the $\mathrm{Sr}_{2} \mathrm{~B}_{2} \mathrm{O}_{5}$ and rutile phase respectively in all the shown micrographs. Glass sample $\mathrm{B} 1$ (figure $6 \mathrm{a}$ ) subjected to heat treatment at $800^{\circ} \mathrm{C}$ for $6 \mathrm{~h}$ with slow heating rate $\left(2^{\circ} \mathrm{C} / \mathrm{min}\right)$ reveals the initial growth of different phases viz. $\mathrm{Sr}_{2} \mathrm{~B}_{2} \mathrm{O}_{5}, \mathrm{Sr}_{3} \mathrm{Ti}_{2} \mathrm{O}_{7}$ and $\mathrm{TiO}_{2}$ (rutile) etc. XRD pattern for this glass ceramic sample is more complex because of the small volume fraction of crystalline phases in glassy matrix. Particle size falls in the submicron range with uniform distribution of crystallites. Higher crystallization temperature $\left(\geqslant 900^{\circ} \mathrm{C}\right.$ ) for glass $\mathrm{B} 1$ (figure 6b) gives acicular type crystallites of $\mathrm{Sr}_{2} \mathrm{~B}_{2} \mathrm{O}_{5}$ phase. This micrograph reveals the growth of secondary crystalline phases from the surface of primary crystals with well defined angles. During growth, bismuth ions may remain at glass/crystal interface leading to some nucleating centres and promoting growth from the surface of primary crystals. Figure $6 \mathrm{c}$ depicts a micrograph for glass ceramic sample no. B1H which shows the precipitation of $\mathrm{TiO}_{2}$ (rutile) and $\mathrm{SrTiO}_{3}$ phases. Spherical and fibrous crystallites were observed which fall in micron and submicron range respectively. With the increase in $\mathrm{Bi}_{2} \mathrm{O}_{3}$ content to $5 \mathrm{wt} \%$ microstructure results into fine grains of submicron size (figure $6 \mathrm{~d}, \mathrm{e}$ ) indicating very large nucleating rate and hence minimal growth of crystallites. It might be possible that in the composition range of $\mathrm{B} 5$ there are large number of $\mathrm{BiO}_{3}$ groups of $\mathrm{C}_{3 \mathrm{v}}$ type acting as nucleating agents. Glass $\mathrm{B} 10$ heat treated at $900^{\circ} \mathrm{C}$ shows (figure 6f) enhanced growth and well developed secondary phases. Micrograph shows larger grain size of uniformly distributed $\mathrm{Sr}_{2} \mathrm{~B}_{2} \mathrm{O}_{5}$ phase. At $950^{\circ} \mathrm{C}$ crystallization temperature, borate phase becomes continuous and other secondary phases viz. rutile, $\mathrm{Sr}_{3} \mathrm{Ti}_{2} \mathrm{O}_{7}$ dispersed filling the gap between borate grains. It seems 

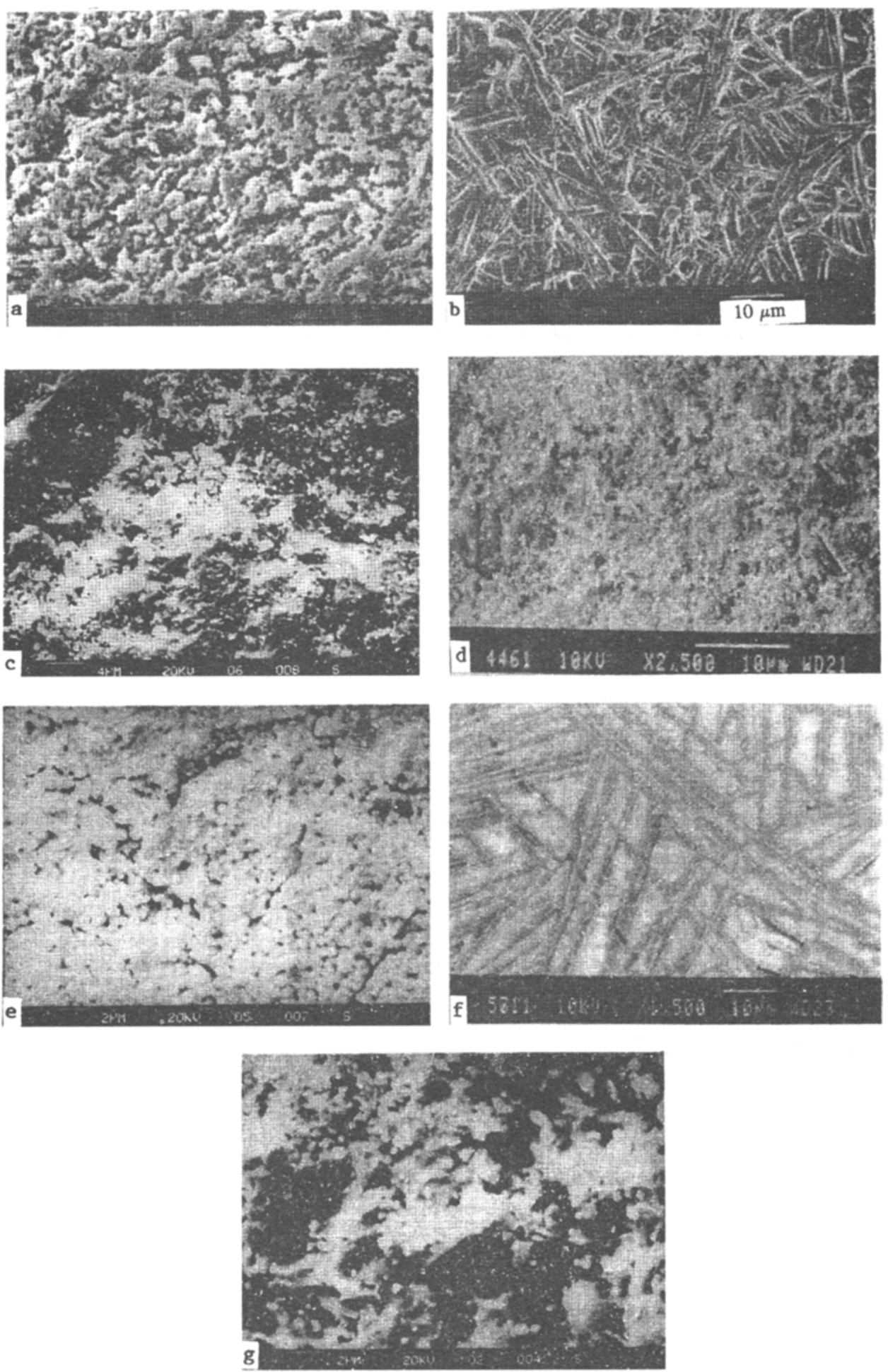

Figure 6. Scanning electron micrographs of glass ceramic sample nos. (a) B1A, (b) B1C, (c) B1H, (d) B5A, (e) B5D, (f) B10A and (g) B10D. 
that the recovery of crystalline phases is almost complete for this glass composition. Figure $6 \mathrm{~g}$ shows the micrograph for glass ceramic sample no. B10D which demonstrates the presence of two phases viz. $\mathrm{SrTiO}_{3}$ and $\mathrm{TiO}_{2}$.

\section{Conclusions}

(I) From the present investigation and earlier work, it was difficult to crystallize $\mathrm{SrTiO}_{3}$ phase in resultant glass ceramics due to the competition of $\mathrm{SrO}$ among different crystalline phases. But, by direct insertion of glass specimen (glass B1) at higher crystallization temperature $\left(\approx 1000^{\circ} \mathrm{C}\right)$, it could be possible to precipitate out $\mathrm{SrTiO}_{3}$ because sufficient amount of $\mathrm{SrO}$ is available to react with $\mathrm{TiO}_{2}$ in test glass samples.

(II) Strontium titanate phase also appears in case of glass ceramic sample no. B10D by choosing proper heat treatment schedule. It seems that at higher $\mathrm{Bi}_{2} \mathrm{O}_{3}$ content $(10 \mathrm{wt} \%)$ in base glass, some structural change occurs in the glass having 4-fold coordinated boron which results in redissolution of earlier formed phases, such as $\mathrm{Sr}_{2} \mathrm{~B}_{2} \mathrm{O}_{5}$ and $\mathrm{Sr}_{3} \mathrm{Ti}_{2} \mathrm{O}_{7}$ to give $\mathrm{SrTiO}_{3}$.

(III) For most of the heat treatments, $\mathrm{Sr}_{2} \mathrm{~B}_{2} \mathrm{O}_{5}$ appears as primary crystalline phase followed by $\mathrm{TiO}_{2}, \mathrm{Sr}_{3} \mathrm{Ti}_{2} \mathrm{O}_{7}$ and some unidentified phases. The crystallization study for glass $\mathrm{B} 5$ supports the formation of $\mathrm{TiO}_{2}$ (rutile) phase while glasses $\mathrm{B} 1$ and $\mathrm{B} 10$ assists the $\mathrm{Sr}_{2} \mathrm{~B}_{2} \mathrm{O}_{5}$ phase to form.

(IV) Glass ceramics derived from glass B5 result in fine grains of submicron size which shows higher nucleation rate and minimal crystal growth.

\section{Acknowledgements}

One of the authors (OPT) is indebted to the Department of Atomic Energy, Mumbai for awarding Dr K S Krishnan Research fellowship. Partial financial support from UGC and CSIR, New Delhi is gratefully acknowledged.

\section{References}

Anderson S, Bolion R K and Kimpton D P 1955 J. Am. Ceram. Soc. 38370

Bishay A M and Maghrabi C 1969 Phys. Chem. Glasses 101

Grossman D G and Isard J O 1969 J. Mater. Sci. 41059

Herczog A 1964 J. Am. Ceram. Soc. 47107

Kokubo T and Tashiro M J 1973/74 Non-cryst. Solids 13328

Kokubo T, Kung C and Tashiro M J 1968 Ceram. Assoc. Jpn. 7689

Krogh-Moe J 1965 J. Phys. Chem. Glasses 646

Lawless W N 1972 U.S. Patent No. 3, 649, 891

Martin F W 1965 Phys. Chem. Glasses 6143

McMillan P W 1979 Glass ceramics (London:Academic Press) 2nd ed.

Parkash Om, Kumar Devendra and Pandey Lakshman 1986 Bull. Mater. Sci. 8557

Simon I 1960 in Modern aspects of the vitrous state (London:Butterworth) p. 138

Swartz S L, Lanagan M T, Schulze and Cross L E 1983 Ferroelectrics 50313 
Swartz S L, Breval E, Randall C A and Fox B H 1988a J. Mater. Sci. 233997

Swartz S L, Breval E and Bhalla A S 1988b Am. Ceram. Soc. Bull. 67763

Thakur O P, Kumar Devendra, Parkash Om and Pandey Lakshman 1995a Bull. Mater. Sci. 18577

Thakur O P, Kumar Devendra, Parkash Om and Pandey Lakshman 1995b Mater. Lett. 23253

Thakur O P, Kumar Devendra, Parkash Om and Pandey Lakshman 1996 Bull. Mater. Sci. 19393 